\title{
EFFECT OF MERCURIC COMPOUNDS ON THE MATERNAL TRANSMISSION OF SELENIUM IN THE PREGNANT AND LACTATING RAT
}

\author{
J. PAŘ̃IZEK, I. OŠŤÁDALOVÁ, J. KALOUSKOVÁ, A. BABICKÝ, \\ L. PAVLIK AND B. BÍBR
}

Institute of Physiology, and Radioisotope Laboratories of the Institutes for

Biological Research, Czechoslovak Academy of Sciences, Prague

(Received 21st May 1970, revised 17th September 1970)

\begin{abstract}
Summary. The administration of small amounts of mercuric compounds to pregnant rats, injected with ${ }^{75} \mathrm{Se}$ in the form of selenite, markedly increased their retention of ${ }^{75} \mathrm{Se}$ and simultaneously decreased the ${ }^{75} \mathrm{Se}$ content in their foetuses. The ${ }^{75} \mathrm{Se}$ concentration in the blood and liver of foetuses from these rats was much lower than in the blood and liver of foetuses from control mothers injected with [ $\left.{ }^{75} \mathrm{Se}\right]$ selenite only (or receiving zinc chloride instead of mercuric chloride). Retention of ${ }^{75} \mathrm{Se}$ in the maternal organs and the passage of ${ }^{75} \mathrm{Se}$ into the foetuses was partially dependent on the dose of mercury. In the doses used in these experiments, administration of mercuric salts did not result in foetal death nor in any significant effect on the weight of the offspring. In lactating rats, the administration of mercuric salts had a similar effect on the passage of ${ }^{75} \mathrm{Se}$ into the milk. This resulted in a much smaller ${ }^{75} \mathrm{Se}$ content in the newborn and suckling young of mothers exposed to small amounts of mercuric compounds during pregnancy or lactation than in control animals.
\end{abstract}

\section{INTRODUCTION}

Following the discovery that selenium is an essential nutrient (Schwarz \& Foltz, 1957) and the first report revealing that prenatal myopathy in lambs can be prevented by adding a small amount of selenium to a dystrophogenic diet fed to pregnant ewes (Muth, Oldfield, Remmert \& Schubert, 1958), the importance of selenium in the prevention and therapy of analogous livestock diseases affecting various animal species was confirmed by a great number of authors (see Rosenfeld \& Beath, 1964; Muth, 1967).

Selenium concentrations in various organs (such as liver, kidneys or blood) of foetal or newborn lambs were reported to be markedly lower in flocks affected with congenital white muscle diseases than in those that were unaffected (Cousins \& Cairney, 1961; Burton, Keeler, Swingle \& Young, 1962; Hartley, 1967). Low tissue levels of selenium in the organs of young animals appear to be an essential prerequisite for the development of selenium-responsive diseases during this period of life, though some reports indicate that the incidence of these diseases may not always be connected with demonstrable 
selenium deficiency in the feed (Schwarz \& Mertz, 1960; Schubert, Muth, Oldfield \& Remmert, 1961; Hartley \& Grant, 1961). It seems reasonable to expect that during pregnancy and lactation, the interfering factors could act not only at the level of the availability of selenium for the maternal organism but also at the level of the transmission of selenium from the maternal organism into the foetuses and the milk.

The administration of small amounts of salts of certain metals such as cadmium (Ganther \& Baumann, 1962; Pařízek, Oštádalová, Beneš, Babický \& Beneš, 1967; Pař́zek, Beneš, Babický, Procházková \& Lener, 1969b), mercury (Pařízek et al., 1967, 1969b; Levander \& Argrett, 1969) or thallium (Levander \& Argrett, 1969) affects selenium metabolism, markedly decreasing its excretion from the organism, and it is known that some of these metals, particularly cadmium, may be present in fertilizers (Schroeder, 1963, 1967) and surprisingly large amounts of mercury compounds (see Bidstrup, 1964; Warren, Delavault \& Cross, 1965) have been used in agriculture (seed dressing). It might be expected that, as a result of certain of these man-made changes in the environment connected with industrialization and agricultural development, living organisms might be exposed to significant amounts of compounds of these metals.

Earlier experiments have shown that the interrelationship between selenium and the metals, mercury, cadmium and thallium could have special implications during pregnancy and lactation, and that small amounts of selenium compounds given during pregnancy or lactation decreased the passage of mercury from the maternal organism into the offspring (Pařizek, Beneš, Oštádalová, Babický, Beneš \& Piłha, 1969d; Pařízek, Babický, Oštádalová, Kalousková \& Pavlík, 1969a). It seemed of interest, therefore, to learn if small amounts of salts of these metals given during pregnancy and lactation could have a similar effect on the passage of selenium into the offspring, changing not only the excretion of selenium from the maternal organism but also its transmission into the foetuses and the milk.

As cadmium salts, in contrast to those of mercury, produced serious damage in the placentae (Pařízek, 1964) and lactating mammary glands (Pařízek et al., 1969d) and as mercuric compounds seem to be more potent in affecting selenium metabolism (Pařízek et al., 1969b), small amounts of salts of bivalent mercury were given to pregnant or lactating rats injected with a tracer dose of $\left[{ }^{75}\right.$ Se]selenite. In order to avoid possible interference at the level of intestinal absorption, the metallic salts were administered parenterally. The effect of the mercury on the retention of selenium in the maternal organism and on its passage into the foetuses and into the milk and sucklings was compared with the effect of salts of the chemically homologous element, zinc. A preliminary report on the results of these experiments has already appeared (Pařizek, Oštádalová, Kalousková, Babický \& Pavlík, 1969e; Pařízek, Oštádalová, Kalousková \& Babický, 1970).

\section{MATERIALS AND METHODS}

Pregnant or lactating rats (Wistar, substrain Konárovice) were kept under 
constant laboratory conditions and fed a standard laboratory diet (Oštádalová \& Pařízek, 1968). The day on which sperm cells were detected in vaginal smears was taken as the lst day of pregnancy. In the experiments on lactating rats, the number of sucklings in each litter was kept constant from the 2nd day after delivery so that eight sucklings were fed by each lactating rat.

The radioisotope of selenium was obtained as sodium $\left[{ }^{75} \mathrm{Se}\right]$ selenite from the Radiochemical Centre, Amersham, and diluted with saline so that the amount of radioisotope injected per $100 \mathrm{~g}$ of body weight was contained in a volume of $0.1 \mathrm{ml}$.

Mercuric chloride, mercuric acetate or zinc chloride (Lachema; the highest grade of purity) were injected as $0.02 \mathrm{M}$-solutions, with the exception of the experiments in which the effects of various doses of mercury were compared and in which correspondingly more dilute solutions were used. All solutions were made isotonic with saline and injected subcutaneously $1 \mathrm{hr}$ before the injection of the radioisotope of selenium. The radioisotope and the solutions of salts of the metals used were injected into different regions of the body to avoid direct contact of solutions injected into the same rat.

For the determination of radioactivity in vivo in pregnant rats, lactating rats and whole litters, and also for radioactivity determination of larger samples (whole maternal liver, whole non-dissected uteri, all placentae and all foetuses from each pregnant rat), a whole-body counter was used. The detectors of the whole-body counter consisted of two $\mathrm{NaI}(\mathrm{Tl})$ crystals $(6 \mathrm{in} . \times 4$ in. and 4 in. $\times 4$ in.) shielded by 2 in. of steel. The electronic equipment consisted of an E.H.T. power supply, a photomultiplier balancing unit, a signal adding unit, a linear pulse amplifier and a one-channel gamma spectrometer. With the exception of the gamma spectrometer (Vacutronic), all other electronic parts and the detectors were supplied by Nuclear Enterprises (G.B.) Ltd. The measurements were taken at the photopeak of the ${ }^{75} \mathrm{Se}(0.40 \mathrm{MeV})$.

After determination of the radioactivity in vivo, the pregnant rats were killed by decapitation and maternal blood and liver samples were collected. In the experiments in which the ${ }^{75} \mathrm{Se}$ content was determined in foetal blood and liver, the foetuses were removed and also killed by decapitation immediately after the death of the mothers: foetal blood and liver samples were pooled from all the foetuses of each pregnant rat. In other experiments where the total radioactivity present in the whole uterus and in its components was determined, the uteri were removed in toto immediately after decapitation of the pregnant rats and the radioactivity was determined using the whole-body counter. Immediately thereafter, the uteri were dissected and all placentae and all foetuses from each pregnant rat were collected and pooled and their radioactivity was determined using the whole-body counter.

Milk samples were collected by manual expression from lactating rats from which the sucklings were removed $1 \mathrm{hr}$ before the injection of the radioisotope, i.e. $25 \mathrm{hr}$ before the milk collection. Immediately after the milk collection, the lactating rats were killed by decapitation and their blood and blood plasma were collected.

For the determination of radioactivity of smaller samples $(1 \mathrm{ml}$ of maternal blood and blood plasma or pre-weighed samples of maternal blood, foetal 
blood, foetal liver and milk), a well-type $\mathrm{NaI}(\mathrm{Tl})$ crystal and a scaler (Versamatic, Tracerlab) were used.

Appropriate standards were measured together with samples using the wholebody counter in addition to the well-crystal. Particular care was given to the geometry of measurement: the conditions used excluded the possibility of any significant error arising from any possible lack of homogeneity in the distribution of the isotope within the measured organism or samples. The results were expressed as a percentage of the injected dose of ${ }^{75} \mathrm{Se}$ except in Text-fig. 3, where the content of ${ }^{75} \mathrm{Se}$ in all foetuses from each rat was expressed as a percentage of the total amount of ${ }^{75} \mathrm{Se}$ retained in the whole pregnant rat at the time at which the mothers were killed and the foetuses were removed.

The mean values $\left( \pm\right.$ S.E.) for the ${ }^{75}$ Se content are given in Text-figs. 1 to 5 and Tables 1 and 2. Where appropriate, Fisher's $t$ test or analysis of variance were used for statistical evaluation of the results, and the method of least squares for fitting the regression lines.

\section{RESULTS}

As shown in Text-fig. 1, exposure of the pregnant rats to mercuric chloride increased the ${ }^{75} \mathrm{Se}$ concentration in the maternal blood $(P<0.01)$ and liver $(P<0.05)$. In spite of the markedly increased ${ }^{75} \mathrm{Se}$ level in the blood on the maternal side of the placenta, ${ }^{75} \mathrm{Se}$ concentrations in the blood and liver of foetuses from mercuric-chloride-treated mothers were substantially decreased in comparison with the levels found in foetuses of control pregnant rats given $\left[{ }^{75} \mathrm{Se}\right]$ selenite only $(P<0.01)$. Equimolar or even higher doses of zinc chloride did not have a similar effect to mercuric chloride. There was no significant effect on the ${ }^{75} \mathrm{Se}$ concentration in the maternal organs or on the level in the foetal blood, nor was there any decrease of the level in the foetal liver. On the contrary, a statistically significant $(P<0.01)$ increase of the ${ }^{75} \mathrm{Se}$ concentration was observed in the liver of foetuses of mothers treated with zinc chloride in comparison with controls receiving the tracer dose of selenite only. Further experiments are necessary to understand the mechanism of this effect of zinc.

In further experiments, a study was made of the dependence of the maternal retention of ${ }^{75} \mathrm{Se}$ (and its passage into the foetuses) on the dose of mercuric chloride given to pregnant rats. As shown in Text-fig. 2, even a small amount of mercuric chloride increased the retention of selenium in the whole maternal organism and simultaneously decreased the passage of selenium into the foetuses. As a result of this, a much smaller proportion of the whole amount of ${ }^{75} \mathrm{Se}$ retained in the pregnant rats was present in foetuses of rats given mercuric chloride (Text-fig. 3). The effect both on the retention of selenium in the pregnant rat and on its transmission into the foetuses was, within certain limits, dependent on the dose of mercury, though this dependence was not linear in character.

For a mathematical description of the relationship between the variables given in Text-figs. 2 and 3, the empirical formulae were compared with the experimental data using the method of least squares. The equations of the best- 


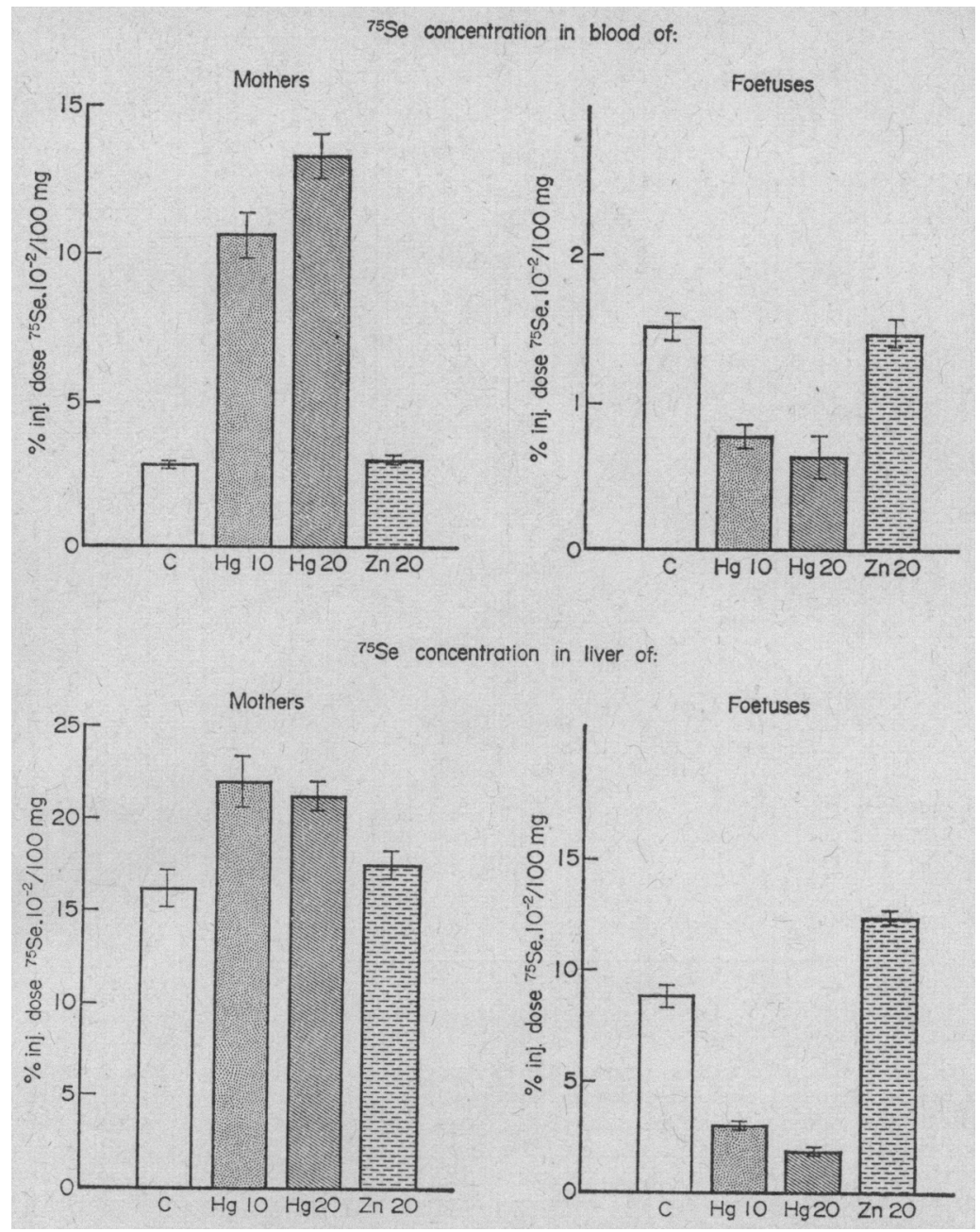

TExT-FIG. 1. The effect of mercuric chloride given to pregnant rats on the distribution of ${ }^{75} \mathrm{Se}$ in maternal and foetal organs. [ ${ }^{75}$ Se] selenite $(200 \mu \mathrm{Ci} / \mathrm{kg}$ b.wt corresponding to $0.68 \mu \mathrm{mol} / \mathrm{kg} \mathrm{b}$.wt) given on the 19th day of pregnancy. C: controls, ${ }^{75} \mathrm{Se}$ only $(n=6)$. $\mathrm{Hg} 10$ : mercuric chloride $10 \mu \mathrm{mol} / \mathrm{kg}$ b.wt $(\mathrm{n}=6) . \mathrm{Hg} 20:$ mercuric chloride $20 \mu \mathrm{mol} / \mathrm{kg}$ b.wt $(n=6)$. Zn20: zinc chloride $20 \mu \mathrm{mol} / \mathrm{kg}$ b.wt $(\mathrm{n}=5)$. Situation $24 \mathrm{hr}$ after the administration of ${ }^{73} \mathrm{Se}$.

fit regression lines expressing the relationship between the dose of mercury given and (1) the retention of ${ }^{75} \mathrm{Se}$ in the whole pregnant rat,

(2) the ${ }^{75} \mathrm{Se}$ content in one foetus (expressed as a percentage of the injected dose of ${ }^{75} \mathrm{Se}$ ), and

(3) the total ${ }^{75} \mathrm{Se}$ content in all foetuses from each pregnant rat (expressed as a percentage of the actual total amount of ${ }^{75} \mathrm{Se}$ retained in the whole pregnant rat) can be given as

$$
\frac{1}{y_{1}}=0.01462 e^{-0.446 x}+0.01130, \text { where } x \text { is the dose of mercury }
$$

injected $(\mu \mathrm{mol} / \mathrm{kg} \mathrm{b} . \mathrm{wt})$ and $\mathrm{y}_{1}$ is the amount of ${ }^{75} \mathrm{Se}$ retained in the whole 


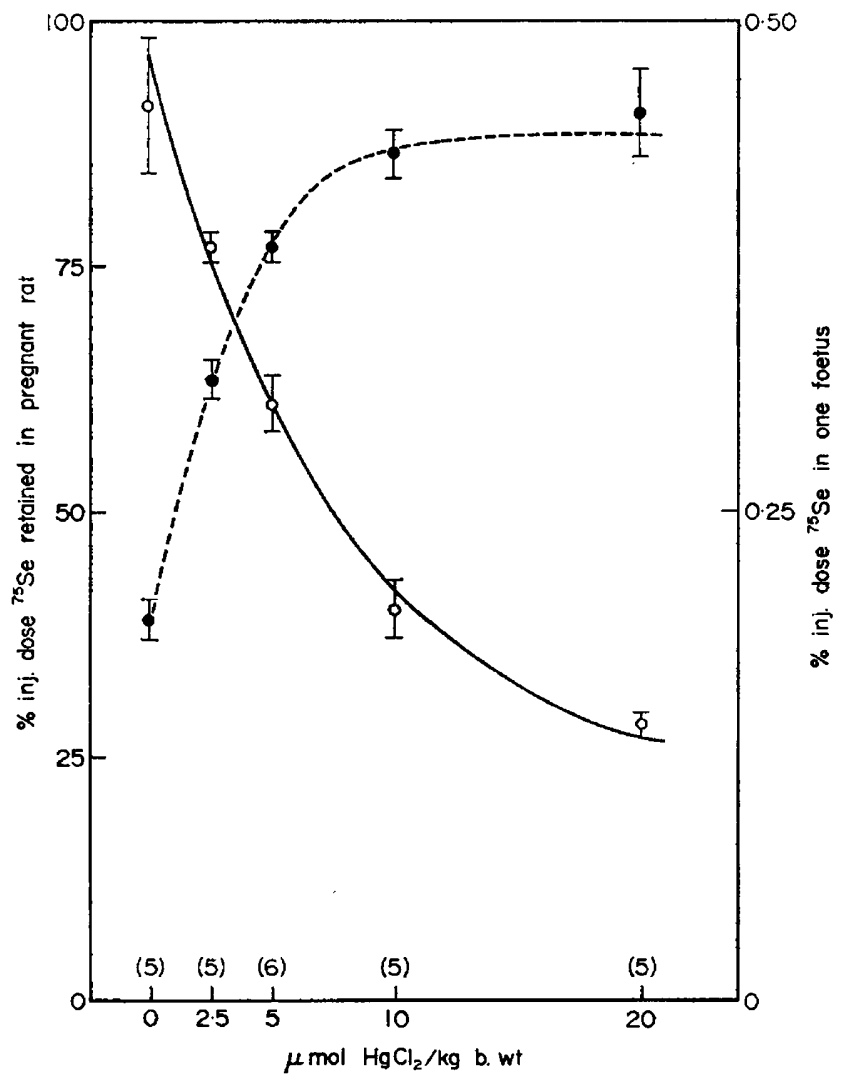

Text-Fig. 2. The effect of mercuric chloride on the retention of the ${ }^{75} \mathrm{Se}$ in pregnant rats and on the passage of ${ }^{75}$ Se from the maternal organism into foetuses: the dependence on the dose of mercury. $\left[{ }^{75} \mathrm{Se}\right]$ selenite $(100 \mu \mathrm{Ci} / \mathrm{kg}$ b.wt corresponding to $3.6 \mu \mathrm{mol} / \mathrm{kg} \mathrm{b} . \mathrm{wt})$ given on the 19th day of pregnancy. Situation $20 \mathrm{hr}$ after the ${ }^{75} \mathrm{Se}$ administration. Experimental data (means \pm S.E.) for the ${ }^{75} \mathrm{Se}$ content in one foetus $(0)$ and in the pregnant rat (O) as well as the corresponding best-fit curves are represented. The numbers in parentheses are of pregnant rats.

pregnant rat (expressed as a percentage of the dose of ${ }^{75} \mathrm{Se}$ injected). In that case,

$$
\lim _{x \rightarrow \infty} y_{1} \doteq 88 \cdot 5 \% \text {. }
$$

$$
y_{2}=0 \cdot 377 e^{-0.126 x}+0 \cdot 104 \text {, }
$$

where $\mathrm{x}$ is the dose of mercury ( $\mu \mathrm{mol} / \mathrm{kg} \mathrm{b}$.wt) injected into a pregnant rat and $y_{2}$ is the amount of ${ }^{75} \mathrm{Se}$ present in one foetus (expressed as a percentage of the dose of ${ }^{75} \mathrm{Se}$ injected). In that case,

$$
\begin{aligned}
& \lim _{x \rightarrow \infty} y_{2}=0 \cdot 104 \% . \\
& y_{3}=8 \cdot 24 e^{-0.245 x}+1 \cdot 30,
\end{aligned}
$$

where $x$ is the dose of mercury $(\mu \mathrm{mol} / \mathrm{kg}$ b.wt) injected into a pregnant rat and $y_{3}$ is the total ${ }^{75}$ Se content in all foetuses from each pregnant rat (expressed as a percentage of the actual amount of the ${ }^{75} \mathrm{Se}$ retained in the whole pregnant rat). In that case, 


$$
\lim _{x \rightarrow \infty} y_{3}=1 \cdot 30 \% \text {. }
$$

The organ distribution of ${ }^{75} \mathrm{Se}$ in pregnant rats treated with various doses of mercuric chloride is given in Table 1 . By increasing the dose of mercuric chloride, the concentration of ${ }^{75} \mathrm{Se}$ increased in all the maternal organs studied and decreased in the foetuses. When the ${ }^{75} \mathrm{Se}$ content was determined in samples containing both maternal and foetal components (whole nondissected uteri, placentae), the dependence of the ${ }^{75} \mathrm{Se}$ content on the dose of mercury had a different character than in the case of maternal blood and liver (Table I).

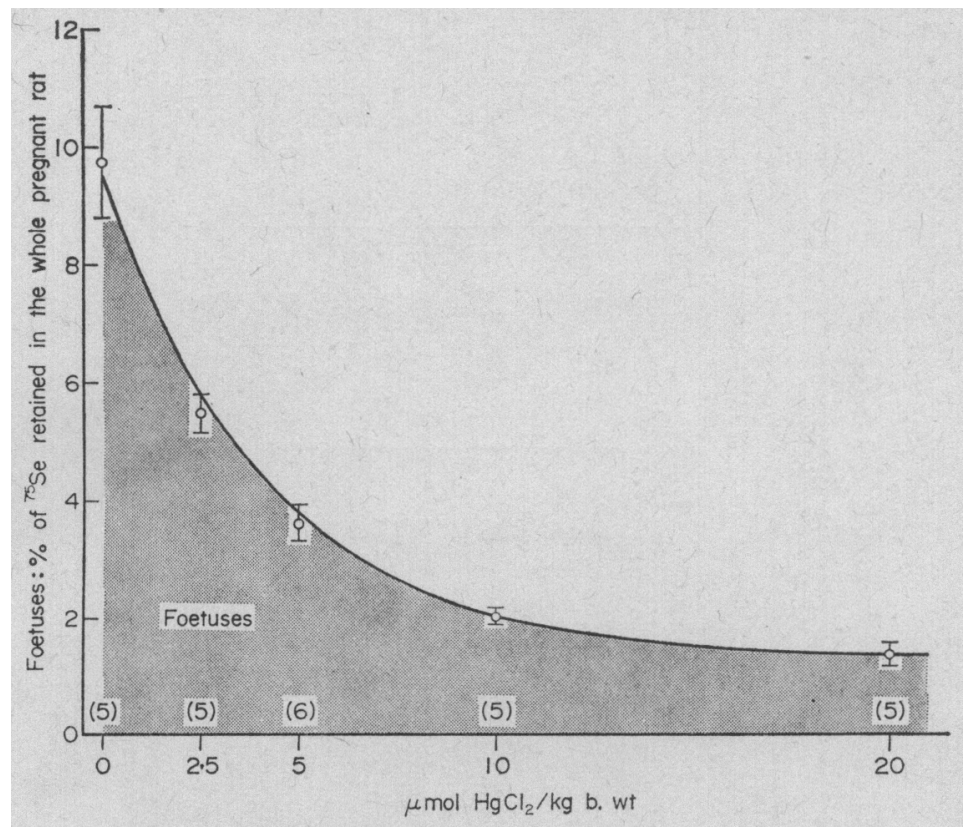

TEXT-FIG. 3. The effect of mercuric chloride given to the mother on the ${ }^{75} \mathrm{Se}$ content of foetuses (expressed as a percentage of the total amount of ${ }^{75} \mathrm{Se}$ retained in the pregnant rat). The same conditions as in the Text-fig. 2, but here the total ${ }^{75} \mathrm{Se}$ content in all foetuses from each rat is given and expressed as a percentage of the total amount of ${ }^{75} \mathrm{Se}$ retained in the whole pregnant rat.

All foetuses were found alive at the time when the pregnant rats were killed and no significant difference was observed in the weight of the placentae and foetuses in controls and in pregnant rats given various doses of mercuric chloride.

A similar effect of bivalent mercury was observed when mercuric acetate was given to pregnant rats and the ${ }^{75} \mathrm{Se}$ content in newborn animals was determined after delivery (Table 2). Even here, the administration of mercuric acetate resulted in an increase in the ${ }^{75}$ Se retention by the mother $(P<0.01)$. In spite of the much higher ${ }^{75} \mathrm{Se}$ content in the mercury-treated mothers, the content in their newborn young was much lower than in those of mothers treated with selenite only $(P<0.01)$. No significant difference was observed in the body weight of the newborn in the two groups. 


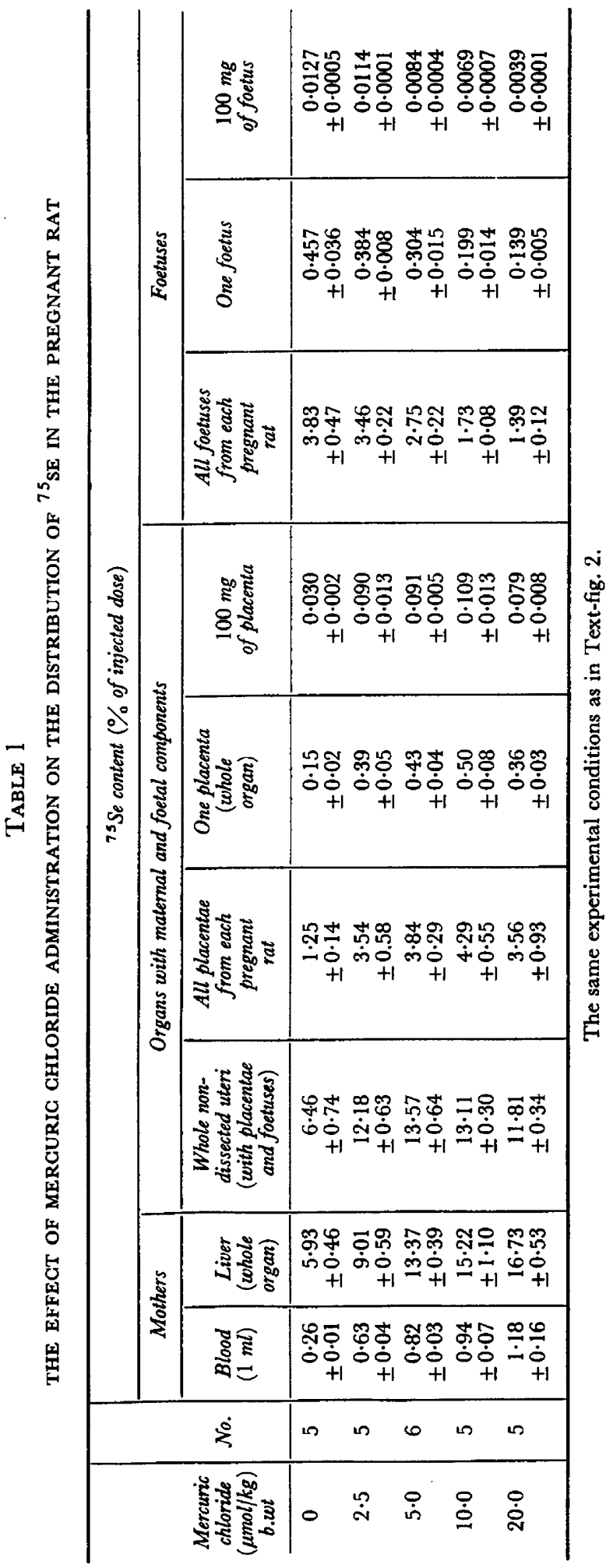


The administration of mercuric chloride to lactating rats had a similar effect on the passage of ${ }^{75} \mathrm{Se}$ across the mammary gland (Text-fig. 4). In spite of an increased ${ }^{75}$ Se level in the blood $(P<0.01)$ and blood plasma $(P<0.01)$ of lactating rats treated with mercuric chloride and given $\left[{ }^{75} \mathrm{Se}\right]$ selenite, the

TABLE 2

THE EFFECT OF MERCURIC ACETATE GIVEN DURING PREGNANCY ON THE ${ }^{75}$ SE CONTENT OF THE NEWBORN YOUNG

\begin{tabular}{|c|c|c|c|c|}
\hline \multirow{3}{*}{ Group } & \multicolumn{3}{|c|}{${ }^{75} \mathrm{Se}$ content $(\%$ of injected dose $)$} & \multirow{3}{*}{$\begin{array}{c}\text { Average } \\
\text { b.wt of } \\
\text { sucklings } \\
(\mathrm{g})\end{array}$} \\
\hline & \multirow{2}{*}{ Mothers } & \multicolumn{2}{|c|}{ Newborns } & \\
\hline & & Whole litter & One suckling & \\
\hline $\begin{array}{c}\mathrm{Se} \\
\mathrm{Hg}-\mathrm{Se}\end{array}$ & $\begin{array}{l}45 \cdot 23 \pm 0 \cdot 75 \\
81 \cdot 00 \pm 3 \cdot 34\end{array}$ & $\begin{array}{r}16 \cdot 66 \pm 1 \cdot 00 \\
5 \cdot 11 \pm 0 \cdot 54\end{array}$ & $\begin{array}{l}1.83 \pm 0.13 \\
0.60 \pm 0.03\end{array}$ & $\begin{array}{l}6.4 \pm 0.3 \\
6 \cdot 2 \pm 0.6\end{array}$ \\
\hline
\end{tabular}

The radioisotope of ${ }^{75} \mathrm{Se}$ in the form of sodium selenite $(100 \mu \mathrm{Ci} / \mathrm{kg}$ b.wt corresponding to $3.6 \mu \mathrm{mol} / \mathrm{kg}$ b.wt) injected subcutaneously into pregnant rats on the 21 st day of pregnancy. Se: ${ }^{75}$ Se]selenite only. Hg-Se: mercuric acetate $(5 \mu \mathrm{mol} / \mathrm{kg} \mathrm{b} . \mathrm{wt})$ given subcutaneously $1 \mathrm{hr}$ before the injection of $\left.{ }^{75} \mathrm{Se}\right]$ selenite. Four pregnant rats in each group. The ${ }^{75}$ Se content in the mothers and sucklings determined within $24 \mathrm{hr}$ of delivery, $51 \mathrm{hr}$ after the injection of ${ }^{75} \mathrm{Se}$.

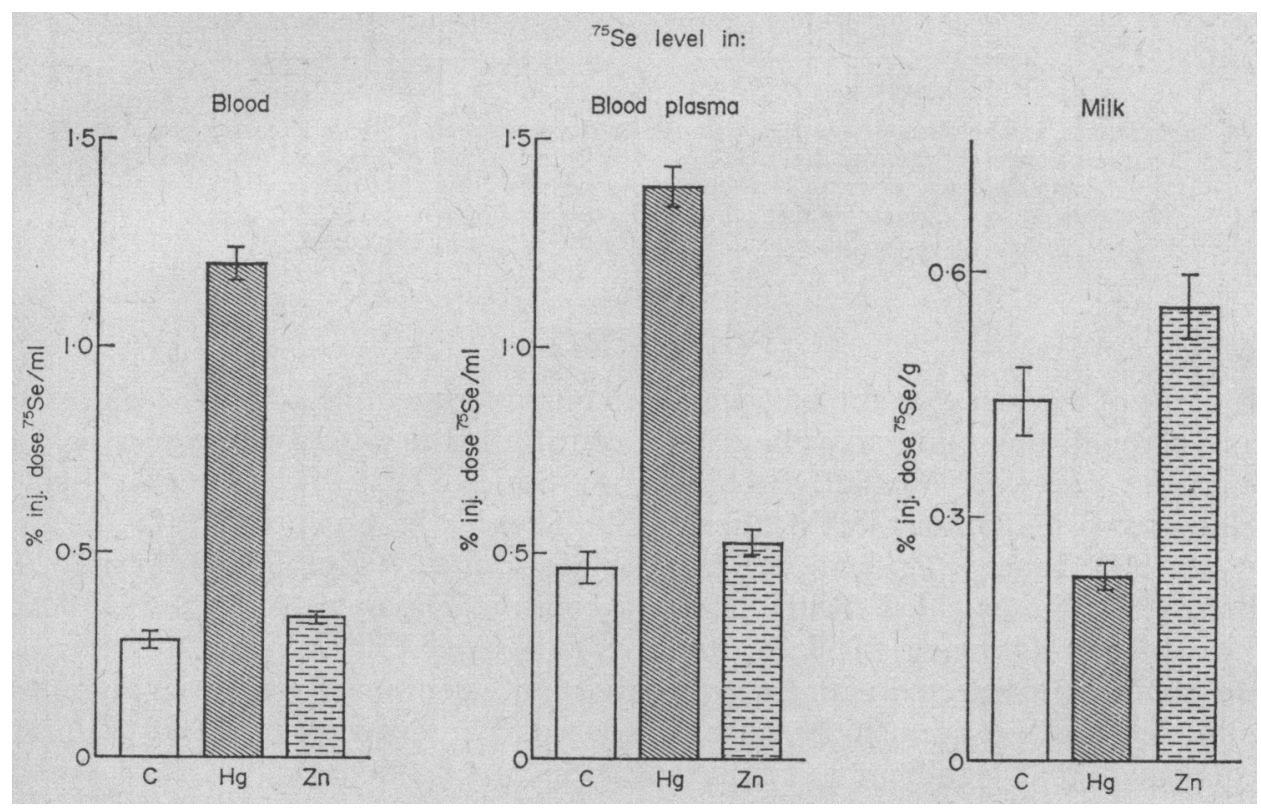

Texr-FIG. 4. The effect of mercuric chloride on the passage of ${ }^{75} \mathrm{Se}$ into milk. $\left[{ }^{75} \mathrm{Se}\right]$ selenite (200 $\mu \mathrm{Ci} / \mathrm{kg}$ b.wt corresponding to $1.3 \mu \mathrm{mol} / \mathrm{kg} \mathrm{b}$.wt) given to lactating rats 15 to 16 days after delivery. C: controls, ${ }^{73} \mathrm{Se}$ only. $\mathrm{Hg}$ : mercuric chloride $5 \mu \mathrm{mol} / \mathrm{kg}$ b.wt. $\mathrm{Zn}$ : zinc chloride $5 \mu \mathrm{mol} / \mathrm{kg}$ b.wt. Seven lactating rats in each group.

${ }^{75} \mathrm{Se}$ concentration in the milk of these rats was lower $(P<0.01)$ than in the milk of control rats treated with selenite only. The analogous injection of zinc chloride given to lactating rats apparently did not affect the ${ }^{75} \mathrm{Se}$ concentration in the blood and blood plasma and did not decrease the ${ }^{75} \mathrm{Se}$ level in the milk. 
An increased ${ }^{75}$ Se level was, in fact, found in the milk of these rats when compared with controls injected with $\left[{ }^{75} \mathrm{Se}\right]$ selenite only $(P<0.05)$.

Mercuric chloride given to lactating rats markedly decreased the passage of ${ }^{75} \mathrm{Se}$ from the mother to the sucklings. As shown in Text-fig. 5, the administration of mercuric chloride resulted in an increased ${ }^{75} \mathrm{Se}$ retention in the maternal organism $(P<0.01)$, and in a simultaneous decrease in the ${ }^{75} \mathrm{Se}$ content in sucklings fed by these rats $(P<0.01)$. No similar effect of zinc chloride administration was observed.

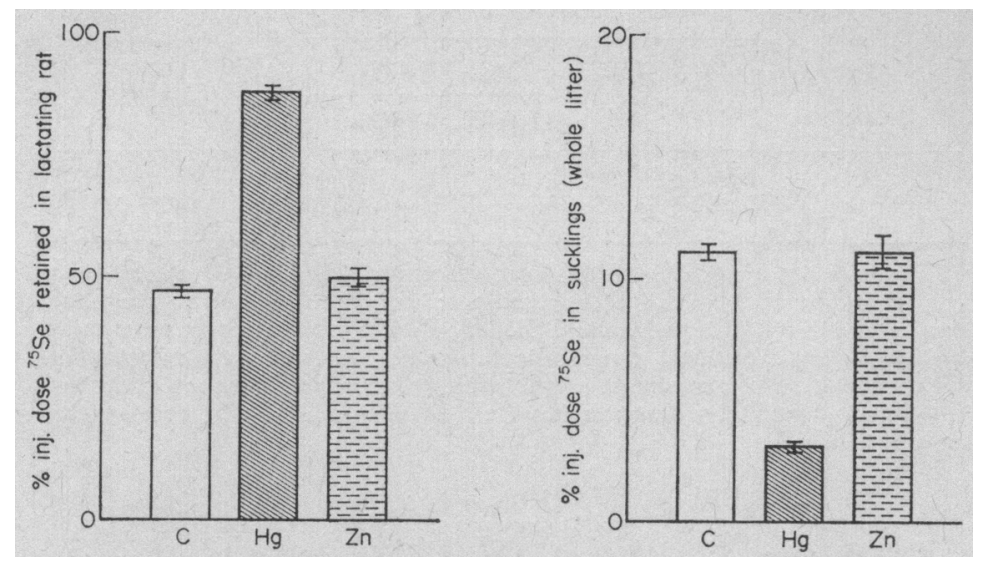

Text-Fig. 5. The effect of mercuric chloride on the retention of ${ }^{75} \mathrm{Se}$ in lactating rats and on the passage of ${ }^{75} \mathrm{Se}$ into the sucklings. [ $\left.{ }^{75} \mathrm{Se}\right]$ selenite $(250 \mu \mathrm{Ci} / \mathrm{kg} \mathrm{b.wt} \mathrm{corresponding}$ to $1.3 \mu \mathrm{mol} / \mathrm{kg} \mathrm{b.wt)}$ given to lactating rats on the 8 th day after delivery. $\mathrm{C}$ : controls, ${ }^{75} \mathrm{Se}$ only $(\mathrm{n}=6)$. $\mathrm{Hg}$ : mercuric chloride $5 \mu \mathrm{mol} / \mathrm{kg} \mathrm{b.wt}(\mathrm{n}=11)$. $\mathrm{Zn}$ : zinc chloride $5 \mu \mathrm{mol} / \mathrm{kg}$ b.wt $(\mathrm{n}=6)$. Situation $24 \mathrm{hr}$ after the ${ }^{75} \mathrm{Se}$ administration.

\section{DISGUSSION}

In spite of the fact that the passage of selenium compounds across the placenta and through the mammary gland has been studied previously by a number of authors (see e.g. Westfall, Stohlman \& Smith, 1938; McConnell, 1948; Hadjimarkos, Bonhorst \& Mattice, 1959; Cousins \& Cairney, 1961; Burton et al., 1962; Jones \& Godwin, 1962, 1963; McConnell \& Roth, 1964; Wright \& Bell, 1964; Rosenfeld \& Beath, 1964; Jacobsson, Oksanen \& Hansson, 1965; Jacobsson \& Oksanen, 1966; Hansson \& Jacobsson, 1966) the exact nature of the processes connected with the transmission of selenium into foetuses and into milk does not yet seem to be fully elucidated. The experiments reported here confirmed that significant amounts of ${ }^{75} \mathrm{Se}$ can be detected in the foetuses and in the milk and sucklings of pregnant or lactating rats given $\left[{ }^{75} \mathrm{Se}\right]$ selenite. Mercuric chloride or mercuric acetate administration had analogous effects on the transfer of ${ }^{75} \mathrm{Se}$ from the maternal organism into the foetuses and into the milk and sucklings which were not shared by zinc chloride. It seems, therefore, that the effect observed can be attributed to mercuric cations, though it is not possible to exclude the fact that salts of some other metals such as cadmium or thallium could act in a similar way. The mathematical analysis of the data given in Text-figs. 2 and 3 suggests that, under the condi- 
tions of the experiment, mercury was not able to effect a complete block to the transfer of ${ }^{75} \mathrm{Se}$ into the foetuses. Thus, the passage of a certain proportion of ${ }^{75} \mathrm{Se}$ - given to the mother in the form of selenite-did not seem to be influenced by the administration of a mercuric salt, even in the highest of those doses which were used.

Two possibilities seem to deserve particular consideration in discussing the mechanisms by which mercury could affect the transmission of ${ }^{75} \mathrm{Se}$ from the maternal organism into the offspring: (a) mercury might act directly on the placenta and on the lactating mammary gland effecting a direct or indirect change in the local conditions which, in turn, may affect the passage of ${ }^{75} \mathrm{Se}$ through these organs; (b) the decreased passage of ${ }^{75} \mathrm{Se}$ into the offspring could result from a change in the chemical form of ${ }^{75} \mathrm{Se}$ in the blood of mercury-treated mothers, so that it could not pass as easily across the barrier represented by the placenta or mammary gland as under normal conditions.

Even if (a) cannot be excluded in full and could, perhaps, play some additional rôle, there would seem to be several points in favour of (b).

Mercuric compounds have been shown to have a similar effect on the transmission of selenium through such different organs as the placenta and the mammary gland and affected a decrease not only in the passage of ${ }^{75} \mathrm{Se}$ into the offspring but also in the excretion of ${ }^{75} \mathrm{Se}$ from the maternal organism in general. This was in good agreement with the effect of mercuric chloride on the excretion of ${ }^{75} \mathrm{Se}$ by non-pregnant and non-lactating rats described earlier (Pařízek et al., 1967, 1969b; Levander \& Argrett, 1969).

No serious damage was detected in the placentae (Paŕízek, 1964) or lactating mammary glands (Pařizek et al., 1969d) of rats injected even with the higher doses of mercuric chloride. This was in accordance with the fact that no foetal death was observed as a result of the administration of mercuric chloride to pregnant rats nor was there any significant difference between the body weight of foetuses and sucklings from mothers treated with mercuric salts and those from control animals.

The second possibility also seems to be supported by the results of previous experiments (Paŕizek et al., 1969a, d) when the administration of selenite to pregnant or lactating rats given a tracer dose of ${ }^{203} \mathrm{Hg}$ increased the retention of mercury in the whole maternal organism and the ${ }^{203} \mathrm{Hg}$ level in the maternal blood, but decreased the passage of ${ }^{203} \mathrm{Hg}$ from the mother to the foetuses and to the milk and sucklings. As reported elsewhere (Pařízek, Beneš, Oštádalová, Babický, Beneš \& Lener, 1969c) a highly increased amount of ${ }^{203} \mathrm{Hg}$ was found in the macromolecular fractions of the blood plasma of rats given selenite and mercuric salts. It has been suggested (Paŕźzek et al., 1969c, d) that a reaction between selenite or some of its metabolites (perhaps bound to proteins) and mercury could explain the pronounced effect of selenium compounds on the toxicity of mercury (Pařizek \& Ošádalová, 1967) and also the altered metabolism of mercury and of selenium in animals receiving simultaneous injections of compounds of both of these elements. The same mechanism could well explain the increased retention of selenium and mercury in the maternal organism and the changed organ distribution of these elements, as well as their decreased passage into foetuses and into milk and sucklings. 
The increased level of ${ }^{75} \mathrm{Se}$ in the blood of mothers treated with mercuric compounds was reflected in the maternal organs, while the foetal blood and organs showed the reverse trend. This seems to be of importance for the interpretation of the results on the ${ }^{75} \mathrm{Se}$ content in whole non-dissected uteri and in the placentae, where both maternal and foetal components were present in the samples analysed. Preliminary experiments revealed that in the mothers given mercuric chloride and $\left[{ }^{75} \mathrm{Se}\right]$ selenite, the radioactivity detected in the placentae could be markedly reduced by perfusing the maternal part of the placentae with saline. This and the comparison of ${ }^{75} \mathrm{Se}$ concentrations found in the placentae and in the maternal blood (Table 1) seem to suggest that a substantial proportion of ${ }^{75} \mathrm{Se}$ found in the placentae of mercury-treated rats could be present in bound form in the maternal blood retained in this organ. This does not exclude the possibility that mercuric salts could directly alter the binding of selenium in the placenta (and in other maternal organs) by a similar mechanism to that which appears to affect the level of ${ }^{75} \mathrm{Se}$ in the blood.

The fact that mercuric compounds seemed to be able to decrease the transmission of selenium to the offspring during the whole period of their nutritional dependence on the maternal organism could have some practical implications from the aspect of the provision of an adequate selenium supply for the developing organism. In the experiments reported here, only the acute effects of a single parenteral administration of inorganic salts of mercury were studied and ${ }^{75} \mathrm{Se}$ was given as sodium selenite. Further experiments should show whether the passage of organic compounds of selenium into the offspring could be affected by administration of mercuric compounds in a similar way and also whether a long-term exposure of pregnant or lactating mothers to very small amounts of inorganic or organic mercuric compounds, given in food or in water, could also decrease the selenium content in the offspring, particularly in animals with a longer period of gestation. It should also be possible to learn how far, in this way, the symptoms of selenium deficiency could be evoked in the newborn and suckling young of mothers exposed to small amounts of salts of certain metals (or, on the other hand, how far salts of these metals given during pregnancy and lactation could prevent the known teratogenic effects of toxic amounts of selenium compounds).

\section{ACKNOWLEDGMENTS}

We would like to thank $\operatorname{Dr} J$. Anděl and Mrs A. Dědičová for their kind advice and help in the statistical evaluation of these results. The technical assistance of Mr J. Klas and Mrs V. Zeniśková is warmly appreciated.

\section{REFERENCES}

Bidstrup, P. L. (1964) Toxicity of mercury and its compounds. Elsevier Publishing Company, Amsterdam. Burton, V., Keeler, R. F., Swingle, K. F. \& Young, S. (1962) Nutritional muscular dystrophy in lambs-selenium analysis of maternal, fetal, and juvenile tissues. Am. J. vet. Res. 23, 1962.

Cousins, F. B. \& CArrnex, I. M. (1961) Some aspects of selenium metabolism in sheep. Aust. J. agric. Res. 12, 927.

Ganther, H. E. \& Baumann, C. A. (1962) Selenium metabolism. I. Effects of diet, arsenic and cadmium. F. Nutr. 77, 210.

Hadjimarkos, D. M., Bonhopst, C. W. \& Mattice, J. J. (1959) The selenium concentration in placental tissue and fetal cord blood. J. Pediat. 54, 296. 
Hansson, E. \& JacoBsson, S. O. (1966) Uptake of ${ }^{75}$ Se-selenomethionine in the tissues of the mouse studied by whole-body autoradiography. Biochim. biophys. Acta, 115, 285.

HARTLEY, W. J. (1967) Levels of selenium in animal tissues and methods of selenium administration. In: Selenium in Biomedicine, p. 79. Ed. O. H. Muth. Avi Publishing Company, Westport, Conn.

Hartley, W. J. \& Grant, A. B. (1961) A review of selenium responsive diseases of New Zealand livestock. Fedn Proc. Fedn Am. Socs exp. Biol. 20, 679.

Jacobsson, S. O. \& Oksanen, H. E. (1966) The placental transmission of selenium in sheep. Acta vet. scand. 7, 66 .

Jacobsson, S. O., Oxsanen, H. E. \& Hansson, E. (1965) Excretion of selenium in the milk of sheep. Acta vet. scand. 6, 299.

Jones, G. B. \& GodwIN, K. O. (1962) Distribution of radioactive selenium in mice. Nature, Lond. $196,1294$.

JonEs, G. B. \& Godwis, K. O. (1963) Studies on the nutritional role of selenium. I. The distribution of radioactive selenium in mice. Aust. F. agric. Res. 14, 716.

LeVANDER, O. A. \& ARgrett, L. C. (1969) Effects of arsenic, mercury, thallium, and lead on selenium metabolism in rats. Toxic. appl. Pharmac. 14, 308.

MaConnelt, K. P. (1948) Passage of selenium through the mammary giands of the white rat and the distribution of selenium in the milk proteins after subcutaneous injection of sodium selenate. 7. biol. Chem. 173, 653.

McConnel., K. P. \& Roth, D. M. (1964) Passage of selenium across the placenta and also into the milk of the dog. F. Nutr. 84, 340 .

Mutr, O. H., Ed. (1967) Selenium in biomedicine. Avi Publishing Company, Westport, Conn.

Muth, O. H., Oldfield, J. E., Remmert, J. R. \& Schubert, J. R. (1958) Effects of selenium and vitamin E on white muscle disease. Science, N.Y. 128, 1090.

Ošŕd́alová, I. \& Paḱizek, J. (1968) Delayed retardation of somatic growth of rats injected with oestrogens during the first days of postnatal life. Physiologia bohemoslov. 17, 217.

PAḰ́zek, J. (1964) Vascular changes at sites of oestrogen biosynthesis produced by parenteral injection of cadmium salts: the destruction of placenta by cadmium salts. 7. Reprod. Fert. 7, 263.

Paḱłzek, J., Babickর́, A., Oštádalová, I., Kalousková, J. \& Pavlí, L. (1969a) The effect of selenium compounds on the cross-placental passage of ${ }^{203} \mathrm{Hg}$. In: Radiation Biology of the Fetal and Juvenile Mammal, p. 137. Eds. M. R. Sikov and D. D. Mahlum. USAEC, Oak Ridge, Tenn.

Pař́zek, J., Beneš, I., Babický, A., Procházková, V. \& Lener, J. (1969b) Metabolic interrelations of trace elements: the effect of mercury and cadmium on the respiratory excretion of volatile selenium compounds. Physiologia bohemoslov. 18, 105.

Paǩízek, J., Beneš, O., OšŤádaloví, I., BabickÝ, A., Beneš, J. \& Lener, J. (1969c) Metabolic interrelations of trace elements: the effect of some inorganic and organic compounds of selenium on the metabolism of cadmium and mercury in the rat. Physiologia bohemoslov. 18, 95.

Paǩ́zek, J., Beneš, I., Ošł́́dalová, I., BabickÝ, A., Beneš, J. \& Pr̛̆Ha, J. (1969d) The effect of selenium on the toxicity and metabolism of cadmium and some other metals. In: Mineral Metabolism in Paediatrics, p. 117. Eds. D. Barltrop and W. L. Burland. Blackwell Scientific Publications, Oxford.

Pax́ízek, J. \& OŠř́́dAlová, I. (1967) The protective effect of small amounts of selenite in sublimate intoxication. Experientia, 23, 142.

Paǩizek, J., Ošł́ádalová, I., Beneš, I., BabickÝ, A. \& Beneš, J. (1967) Ochranný účinek stopových množství seleničitanu při otravě sloučeninami kadmia a dvojmocné rtuti. (The protective effect of trace amounts of selenite in the intoxication with compounds of cadmium and bivalent mercury.) Čslká Fysiol. 16, 41.

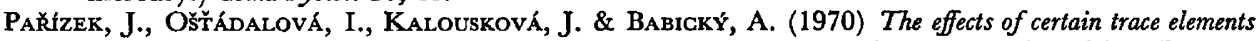
in relation to reproduction. In: Proceedings, VIIIth International Congress on Nutrition, Prague, 1969, Excerpta Medica, Amsterdam.

Pařizek, J., Oštádalová, I., Kalousková, J., Babický, A. \& Pavlík, L. (1969e) Some metabolic implications of the interaction between selenium and some heavy metals during pregnancy and lactation. (Proc. Czechoslov. Physiol. Soc., July, 1969) Physiologia bohemoslov. 18, 502.

Rosengeld, I., \& BeAth, O. A. (1964) Selenium, geobotany, biochemistry, toxicity and nutrition. Academic Press, New York.

Schroeder, H. A. (1963) Cadmium: uptake by vegetables from superphosphate in soil. Science, N.r. 140, 819.

Schroeder, H. A. (1967) Cadmium, chromium and cardiovascular disease. Circulation, 35, 570.

Schubert, J. R., Muth, O. H., Oldfield, J. E. \& Remmert, L. F. (1961) Experimental results with selenium in white muscle disease of lambs and calves. Fedn Proc. Fedn Am. Socs exp. Biol. 20, 689.

Schwarz, K. \& Foltz, C. M. (1957) Selenium as an integral part of Factor 3 against dietary necrotic liver degeneration. F. Am. chem. Soc. 79, 3292. 
Schwarz, K. \& Mertz, W. (1960) Physiological effects of trace amounts of selenium. Proc. Conf. Physiological Aspects of Water Quality, Washington, D.C., p. 79.

Warren, H. V., Delavault, R. E. \& CRoss, C. H. (1965) Some geological factors in medical geography. Sociedad Mexicana de Geographia y Estadistica, Reunion Especial de la Comision de Geographia Medica, Tomo VI, p. 47.

Westfall, B. B., Stohlman, E. F. \& Sмiтh, M. I. (1938) The placental transmission of selenium. 7. Pharmac. exp. Ther. 64, 55.

WRIGHT, P. L. \& BELL, M. C. (1964) Selenium-75 metabolism in the gestating ewe and fetal lamb: effects of dietary $\alpha$-tocopherol and selenium. F. Nutr. 84, 49. 